\title{
Faktor yang Mempengaruhi Loyalitas Pelanggan SPBU Pertamina di
} Jakarta

\author{
Grace Rumondang Ullina Pohan dan Cokki \\ Program Studi Manajemen Fakultas Ekonomi \& Bisnis \\ Universitas Tarumanagara \\ E-mail: grace.115160514@stu.untar.ac.id
}

\begin{abstract}
The purpose of this study is to test the effect of service quality, price perception, and trust directly on customer loyalty or indirectly through customer satisfaction. The population of this study was 100 Pertamina gas station customers in Jakarta. The data collection technique used is convenience sampling by distributing online questionnaires. Data analysis used the Partial Least Square-Structural Equation Modeling (PLS-SEM) technique. The results of this study are service quality and trust affect customer loyalty directly and indirectly through customer satisfaction, but price perceptions can only affect customer loyalty indirectly through customer satisfaction.
\end{abstract}

Keywords: Customer Loyalty, Customer Satisfaction, Service Quality, Perceived Price, Trust.

\begin{abstract}
Abstrak: Tujuan dari penelitian ini adalah untuk menguji pengaruh kualitas pelayanan, persepsi harga, dan kepercayaan terhadap loyalitas pelanggan secara langsung dan tidak langsung melalui kepuasan pelanggan. Populasi dari penelitian ini adalah 100 pelanggan SPBU Pertamina di Jakarta. Teknik pengambilan data yang digunakan adalah convenience sampling dengan menyebarkan kuesioner daring. Data analisis dengan menggunakan teknik Partial Least Square-Structural Equation Modelling (PLS-SEM). Hasil penelitian ini adalah kualitas pelayanan dan kepercayaan mempengaruhi loyalitas pelanggan secara langsung dan secara tidak langsung melalui kepuasan pelanggan, tetapi persepsi harga hanya dapat mempengaruhi loyalitas pelanggansecara tidak langsung melalui kepuasan pelanggan.
\end{abstract}

Kata Kunci: Loyalitas Pelanggan, Kepuasan Pelanggan, Kualitas Pelayanan, Persepsi Harga, Kepercayaan.

\section{LATAR BELAKANG}

Ketika berusaha untuk mengkarakterisasi kesetiaan konsumen, seseorang biasanya mengalami kesulitan dalam mengkarakterisasi pengabdian klien (Chakraborty, 2019). Beberapa konsumen memiliki sikap seperti beralih pada merek baru karena promosi yang gencar. Hal ini sejalan dengan pernyataan (Mathieu \&Zajac, 1990) tentang loyalitas pelanggan dilakukan dari perspektif sikap, mengacu pada faktor psikologis seperti sikap yang menguntungkan dan kemungkinan melakukan pembelian. Sikap lainnya yaitu ketika konsumen memiliki kebutuhan bahan bakar dalam keadaan yang mendesak dan tidak menemukan SPBU Pertamina yang menjadi bahan bakar yang biasa dipakai. Ketika konsumen tersebut merasa lebih puas dengan merek lain itu, konsumen tersebut kemungkinan akan beralih dari bahan bakar SPBU Pertamina. Berdasarkan beberapa sikap pelanggan ini menimbulkan ketidakpastian loyalitas pelanggan terhadap SPBU Pertamina. Loyalitas pelanggan memainkan peran penting dalam mempertahankan dan meningkatkan penjualan (Hur et al., 2010). Lebih penting lagi, loyalitas pelanggan adalah faktor vital untuk meningkatkan laba, karena biaya untuk mendapatkan pelanggan baru diketahui jauh lebih besar daripada biaya yang terlibat dalam melayani pelanggan yang sudah ada (Hur et al., 2010). 


\section{Kajian Teori}

Loyalitas pelanggan adalah kemampuan perusahaan untuk terus memenangkan langganan tetap pelanggan tertentu dari pesaing lain. Ini adalah proses berkelanjutan yang tidak berakhir dengan kepuasan dari kebutuhan pelanggan tetapi lebih berlanjut menjalin hubungan dengan pembelian jangka panjang (Omoregie et al., 2019). Pelanggan menggunakan istilah kepuasan ketika mereka ingin memprediksi bahwa setelah membeli suatu produk / layanan mereka akan puas atau tidak puas (Chakraborty, 2019). Untuk meningkatkan kepuasan pelanggan, harus meningkatkan salah satunya persepsi harga, karena ditemukan memiliki efek terbesar pada kepuasan pelanggan (Ing et al., 2019). Pelanggan pada awalnya juga harus membangun kepercayaan kepada perusahaan yang menawarkan produk atau layanan terbaik kepada pelanggan (Omoregie et al., 2019). Ketika pelanggan mengandalkan produk atau layanan perusahaan, hubungan jangka panjang dapat terjalin erat antara perusahaan dengan pelanggan. Kualitas pelayanan yang konsisten juga merupakan penentu penting loyalitas pelanggan. (Omoregie et al., 2019).

Kualitas pelayanan merupakan kesan, penilaian/ukuran dari pelayanan yang dirasakan pelanggan, yang dapat dilihat dari bukti fisik, keandalan, daya tanggap, jaminan serta empati dari pelayanan tersebut (Kotler \& Armstrong, 2010; Prakash \&Mohanty, 2012;Parasuraman et al., 1985). Persepsi harga merupakan penilaian subyektif pelanggan yang membandingkan kualitas dengan harga yang ditetapkan oleh suatu perusahaan akan suatu produk atau layanan, yang pada umumnya memiliki pemikiran lebih tinggi atau rendahnya harga produk atau layanan tersebut(Zietsman et al., 2018; Lin, 2015; Samah et al., 2015). Kepercayaan merupakan kesediaan yang memiliki harapan terhadap individu atau kelompok yang dapat diandalkan dengan melepas kendali langsung (Rotter, 1967; Moorman et al., 1993; Patrick, 2002). Kepuasan pelanggan merupakan respon konsumen dalam keadaan kognitif yang merupakan penilaian tingkat pemenuhan dari perbandingan antara standar suatu produk atau layanan dengan produk atau layanan yang sebenarnya dirasakan (Iglesias\&Guillén, 2004; Oliver, 2015; Homburg \&Giering, 2001). Loyalitas pelanggan merupakan niat dan komitmen pelanggan untuk melakukan pembelian kembali produk/layanan yang disukai pelanggan dari penjual atau merek yang sama (Oliver, 1999; Hur et al., 2010; Thakur, 2016).

Kaitan antar variabel kualitas pelayanan, persepsi harga, kepercayaan, kepuasan pelanggan dan loyalitas pelanggan. Dalam penelitian Cheng \&Rashid (2013) yang meneliti tentang industri perhotelan di Malaysia, dan penelitian Chakraborty (2019) tentang konsumen muda perkotaan yang loyal terhadap merek tertentu di Kolkata, serta Ing et al. (2019) tentang restoran full-service di Sabah, terdapat hasil penelitian bahwa kualitas pelayanan memiliki pengaruh positif terhadap kepuasan pelanggan. Kemudian terdapat juga hasil penelitian bahwa kualitas pelayanan memiliki pengaruh positif terhadap loyalitas pelanggan dalam penelitian Omoregie et al. (2019) tentang industri perbankan di Ghana, Makanyeza \&Chikazhe (2017) yaitu tentang bank di Zimbabwe, serta penelitian yang dilakukan Slack \&Singh (2020).

Ing et al. (2019) meneliti tentang restoran full-service di Sabah, Han \&Ryu (2009) tentang restoran three full-service di Amerika Serikat, serta penelitian Prayitno (2016) tentang produk batik Indonesia di Surakarta. Dalam ketiga penelitian tersebut terdapat hasil penelitian yaitu persepsi harga memiliki pengaruh yang positif terhadap kepuasan pelanggan. Kemudian terdapat hasil penelitian yaitu persepsi harga memiliki pengaruh yang positif terhadap loyalitas pelanggan terdapat dalam penelitian Han \&Ryu (2009) tentang restoran three full-service di Amerika Serikat, dan penelitian Samah et al. (2015) serta Cheng, Lai \&Yeung (2008) tentang penyedia layanan internet di Hong Kong.

Dalam penelitian Chakraborty (2019) tentang konsumen muda perkotaan yang loyal terhadap merek tertentu di Kolkata, terdapat hasil penelitian bahwa kepercayaan memiliki hubungan yang positif terhadap kepuasan pelanggan, hasil yang sama juga terdapat dalam penelitian Kataria \&Saini (2020) tentang perawatan mulut di India serta Omoregie et al. (2019) 
dalam penelitiannya tentang industri perbankan di Ghana. Penelitian Omoregie et al. (2019) juga terdapat hasil penelitian bahwa kepercayaan memiliki pengaruh positif terhadap loyalitas pelanggan, hasil yang sama juga terdapat dalam penelitian Ramaseshanet al. (2013),serta Quoquab et al. (2019) tentang makanan cepat saji muslim di Kuala Lumpur.

Dalam penelitian Omoregie et al. (2019) terdapat hasil yaitu kepuasan pelanggan memiliki pengaruh positif terhadap loyalitas pelanggan. Hasil yang sam juga terdapat dalam penelitian Han \&Ryu (2009) yang meneliti tentang restoran three full-service di Amerika Serikat, serta penelitian Cheng \&Rashid (2013) tentang industri perhotelan di Malaysia. berikut:

Berdasarkan pemaparan diatas, maka model penelitian dan hipotesisnya adalah sebagai

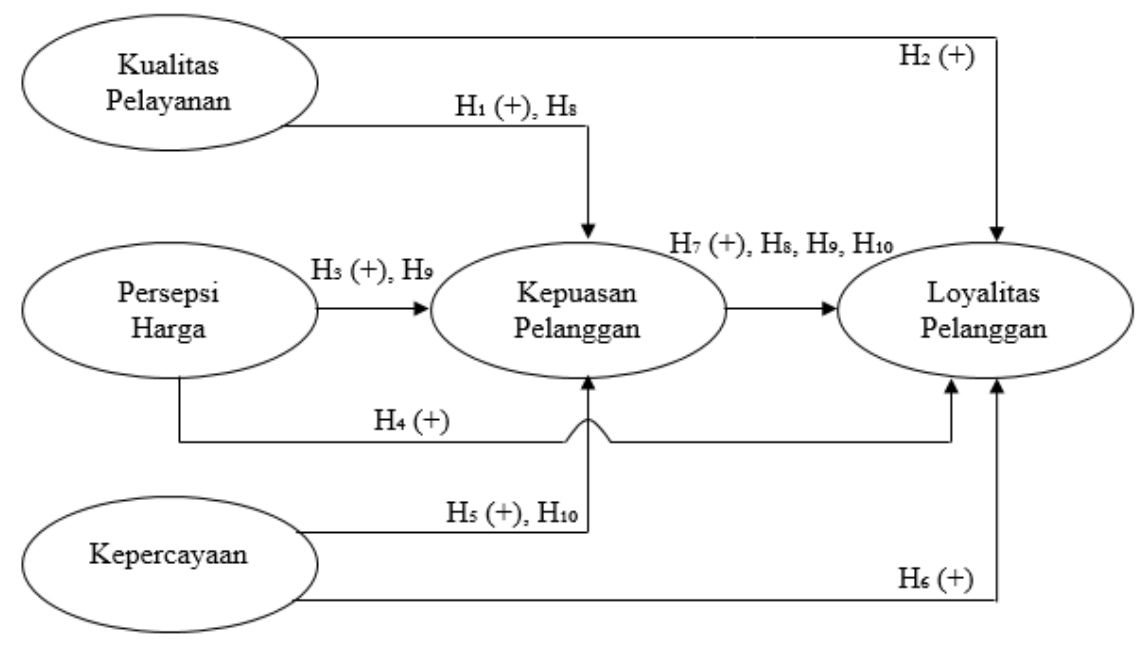

Gambar 1. Model Penelitian

$\mathrm{H}_{1}$ : Kualitas pelayanan memiliki pengaruh yang positif terhadap kepuasan pelanggan.

$\mathrm{H}_{2}$ : Kualitas pelayanan memiliki pengaruh yang positif terhadap loyalitas pelanggan.

$\mathrm{H}_{3}$ : Persepsi harga memiliki pengaruh yang positif terhadap kepuasan pelanggan.

$\mathrm{H}_{4}$ : Persepsi harga memiliki pengaruh yang positif terhadap loyalitas pelanggan.

$\mathrm{H}_{5}$ : Kepercayaan memiliki pengaruh yang positif terhadap kepuasan pelanggan.

$\mathrm{H}_{6}$ : Kepercayaan memiliki pengaruh yang positif terhadap loyalitas pelanggan.

$\mathrm{H}_{7}$ : Kepuasan pelanggan memiliki pengaruh yang positif terhadap loyalitas pelanggan.

$\mathrm{H}_{8}$ : Kualitas pelayanan memiliki pengaruh yang positif terhadap loyalitas pelanggan melalui kepuasan pelanggan.

$\mathrm{H}_{9}$ : Persepsi harga memiliki pengaruh yang positif terhadap loyalitas pelanggan melalui kepuasan pelanggan.

$\mathrm{H}_{1} 0$ : Kepercayaan memiliki pengaruh yang positif terhadap loyalitas pelanggan melalui kepuasan pelanggan.

\section{METODOLOGI}

Penelitian ini menggunakan teknikconvenience sampling. Pengumpulan data dilakukan selama seminggu menyebarkan kuesioner dengan google form melalui media sosial kepada pelanggan SPBU Pertamina di Jakarta.Jumlah responden yang diambil sebanyak 100 responden.

Kualitas pelayanan diukur menggunakan 15 indikator yaitu memahami kebutuhan, sopan, meminta maaf, melayani segera, cepat menanggapi, jawaban cepat, pelayanan menjanjikan, dapat diandalkan, konsisten, lahan cukup, bersih, peralatan modern, layanan tinggi, meningkatkan kepercayaan, dan memiliki pengetahuan (Izogo \&Ogba, 2015; Zhang et al., 2014;Kitapci et al., 2013).Persepsi harga diukur menggunakan 5 indikator yaitu harga wajar, 
daya beli, lebih baik, sesuai kualitas, paham informasi harga (Widyastuti\&Said, 2017; Ing et al., 2019; Rahmawati, 2013). Kepercayaan diukur menggunakan 3 indikator yaitu pengalaman baik, jujur, tidak perlu hati-hati (Chakraborty, 2019; Ramaseshan et al.,2013). Kepuasan pelanggan diukur dengan menggunakan 3 indikator yaitu kebutuhan terpenuhi, pilihan bijaksana, hal benar (Kataria \& Saini, 2020; Ing et al., 2019). Dan terakhir loyalitas pelanggan diukur menggunakan4 indikator yaitu mengatakan hal positif, merekomendasikan, tidak beralih, masa depan (Omoregie et al., 2019; Chakraborty, 2019; Chung et al., 2015).Ukuran semua variabel menggunakan skala Likert 1(Sangat Tidak Setuju)-5(Sangat Setuju).

\section{HASIL UJI STATISTIK}

Responden yang terlibat terdiri dari 62 orang $(62 \%)$ responden pria dan 38 orang (38\%) responden wanita. Usia responden yang lebih mendominasi yaitu 21-30 tahun dengan jumlah total 89 orang responden $(89 \%)$. Pada pendidikan terakhir, pilihan SMA/SLTA dominan dengan total responden sebanyak 51 orang $(51 \%)$ dan pekerjaan yang dominan adalah pelajar/mahasiswa sebanyak 59 orang (59\%). Berdasarkan informasi responden dalam hal usia, pendidikan terakhir dan pekerjaan dapat diartikan bahwa pengisian kuesioner telah diisi oleh orang yang sudah cukup usia untuk memahami pernyataan dengan baik. Informasi pendapatan perbulan memiliki hasil yang dominan yaitu pendapatan diatas Rp 3.000 .000 sebanyak 44 orang (44\%). Hal ini menandakan bahwa mayoritas responden adalah orang yang berkecukupan untuk memenuhi kebutuhan bahan bakarnya di SPBU Pertamina.

Analisis validitas konvergenmenunjukkan bahwa setiap variabel lolos uji karena memiliki nilai AVElebih dari 0.50 (Hair et al., 2011; Tabel 1) dan hasil analisis validitas diskriminan menunjukkan bahwa setiap variabel lolos uji karena memiliki nilai Heterotrait-Monotrait Ratio (HTMT) kurang dari 0.9 (Henseler et al., 2015; Tabel 2).

Tabel 1 . Hasil Analisis Validitas Konvergen dan Reliabilitas Konsistensi Internal

\begin{tabular}{|l|c|c|}
\hline \multicolumn{1}{|c|}{ Variabel / Dimensi } & Average Variance Extracted & Composite Reliability \\
\hline Loyalitas Pelanggan & 0.567 & 0.839 \\
\hline Kepuasan Pelanggan & 0.752 & 0.901 \\
\hline Kualitas Pelayanan & 0.629 & 0.894 \\
\hline Empathy & 0.649 & 0.847 \\
\hline Responsiveness & 0.612 & 0.824 \\
\hline Reliability & 0.525 & 0.765 \\
\hline Tangible & 0.615 & 0.827 \\
\hline Assurance & 0.774 & 0.911 \\
\hline Persepsi Harga & 0.592 & 0.878 \\
\hline Kepercayaan & 0.651 & 0.848 \\
\hline
\end{tabular}

Tabel 2 . Hasil Analisis Validitas Diskriminan

\begin{tabular}{|l|c|c|c|c|}
\hline \multicolumn{1}{|c|}{ Variabel } & Loyalitas P. & Kepuasan P. & Persepsi Harga & K. Pelayanan \\
\hline Kepuasan P. & 0.842 & & & \\
\hline Persepsi Harga & 0.605 & 0.841 & & \\
\hline K. Pelayanan & 0.741 & 0.758 & 0.580 & \\
\hline Kepercayaan K. & 0.863 & 0.882 & 0.612 & 0.804 \\
\hline
\end{tabular}

Kemudian hasil analisis reliabilitas konsistensi internal menunjukkan bahwa setiap variabel lolos uji karena memiliki nilai composite reliabilitylebih dari 0.7 (Hair et al., 2019; Tabel 1) dan hasil analisis reliabilitas indikator menunjukkan bahwa setiap indikator lolos uji karena memiliki nilai diatas 0.6 (Hair et al., 2019; Tabel 3).Selanjutnya hasil uji 
multikolinearitas dilihat dari nilai variance inflation factor (VIF)yang menunjukkan bahwasetiap variabel tidak memiliki multikol karena memiliki nilaitidak lebih dari 5(Hair et al., 2019; Tabel 4).Pada hasil uji $\mathrm{R}^{2}$ terlihat kemampuan yang sedang untuk menjelaskan variabel loyalitas pelanggan dan kepuasan pelanggan karena nilainya berada antara 0.5 dan 0.75(Hair et al., 2019; Tabel 5). Selanjutnya hasil uji relevansi prediksi (Tabel 5) menunjukkan model dianggap relevan untuk mengukur model penelitian yang telah terbentuk sebelumnya dengan baik karenamemiliki nilai $\mathrm{Q}^{2}$ lebih besar daripada 0 (Hair et al., 2011).

Tabel 3 . Hasil Analisis Reliabilitas Indikator

\begin{tabular}{|c|c|c|c|c|c|c|c|c|c|c|c|}
\hline \multicolumn{2}{|c|}{$\begin{array}{c}\text { Loyalitas } \\
\text { Pelanggan }\end{array}$} & \multicolumn{2}{c|}{$\begin{array}{c}\text { Kepuasan } \\
\text { Pelanggan }\end{array}$} & \multicolumn{2}{c|}{$\begin{array}{c}\text { Persepsi } \\
\text { Harga }\end{array}$} & \multicolumn{4}{c|}{ Kualitas Pelayanan } & \multicolumn{2}{c|}{ Kepercayaan } \\
\hline CL1 & 0.725 & CS1 & 0.844 & PP1 & 0.796 & SQ1 & 0.783 & SQ9 & 0.717 & T1 & 0.791 \\
\hline CL2 & 0.853 & CS2 & 0.894 & PP2 & 0.845 & SQ2 & 0.815 & SQ10 & 0.741 & T2 & 0.796 \\
\hline CL3 & 0.656 & CS3 & 0.862 & PP3 & 0.698 & SQ3 & 0.818 & SQ11 & 0.769 & T3 & 0.834 \\
\hline CL4 & 0.765 & & & PP4 & 0.742 & SQ4 & 0.815 & SQ12 & 0.840 & & \\
\hline & & & & PP5 & 0.757 & SQ5 & 0.856 & SQ13 & 0.897 & & \\
\hline & & & & & & SQ6 & 0.662 & SQ14 & 0.903 & & \\
\hline & & & & & & SQ7 & 0.604 & SQ15 & 0.838 & & \\
\hline & & & & & & SQ8 & 0.834 & & & & \\
\hline
\end{tabular}

Tabel 4. Hasil Uji Multikolinearitas

\begin{tabular}{|c|c|c|}
\hline Variabel & Nilai & Keterangan \\
\hline $\mathrm{CL}=\mathrm{f}(\mathrm{CS}, \mathrm{SQ}, \mathrm{PP}, \mathrm{T})$ & $\mathrm{VIF}=3.164$ & Tidak ada \\
$\mathrm{CS}$ & $\mathrm{VIF}=2.062$ & Tidak ada \\
$\mathrm{SQ}$ & $\mathrm{VIF}=1.977$ & Tidak ada \\
$\mathrm{PP}$ & $\mathrm{VIF}=2.251$ & Tidak ada \\
$\mathrm{T}$ & & \\
$\mathrm{CS}=\mathrm{f}(\mathrm{SQ}, \mathrm{PP}, \mathrm{T})$ & $\mathrm{VIF}=1.908$ & Tidak ada \\
$\mathrm{SQ}$ & $\mathrm{VIF}=1.402$ & Tidak ada \\
$\mathrm{PP}$ & $\mathrm{VIF}=1.875$ & Tidak ada \\
$\mathrm{T}$ & \multicolumn{2}{|}{} \\
\hline
\end{tabular}

Tabel 5 . Hasil Analisis $\mathrm{R}^{2}$ dan $\mathrm{Q}^{2}$

\begin{tabular}{|c|c|c|}
\hline Variabel & $\mathbf{R}^{\mathbf{2}}$ & $\mathbf{Q}^{\mathbf{2}}$ \\
\hline Loyalitas Pelanggan & 0.538 & 0.286 \\
\hline Kepuasan Pelanggan & 0.684 & 0.502 \\
\hline
\end{tabular}

Pada hasil uji hipotesis (Tabel 6), hampir semua hipotesis didukung kecuali hipotesis keempat karena tidak memenuhi syarat yaitu $p$-value harus dibawah 0.5. Maka $\mathrm{H}_{1}, \mathrm{H}_{2}, \mathrm{H}_{3}$, $\mathrm{H}_{5}, \mathrm{H}_{6}, \mathrm{H}_{7}, \mathrm{H}_{8}, \mathrm{H}_{9}, \mathrm{H}_{1}$ o didukung dan $\mathrm{H}_{4}$ tidak didukung. Dalam uji mediasi, $\mathrm{H}_{8}$ dan $\mathrm{H}_{1} \quad 0$ merupakan partial mediationkarena dapat mempengaruhi melalui atau tidak melalui mediasi, kemudian $\mathrm{H}_{9}$ merupakan full mediationkarena dapat mempengaruhi ketika melalui mediasi.

Tabel 6 . Hasil Uji Hipotesis

\begin{tabular}{|l|l|c|c|c|}
\hline \multicolumn{1}{|c|}{ Hipotesis } & $\boldsymbol{\beta}$ & P-Values & $\boldsymbol{f}^{\mathbf{2}}$ \\
\hline $\mathrm{H}_{1}$ & Kualitas Pelayanan $\rightarrow$ Kepuasan Pelanggan & 0.221 & 0.006 & 0.081 \\
\hline $\mathrm{H}_{2}$ & Kualitas Pelayanan $\rightarrow$ Loyalitas Pelanggan & 0.193 & 0.031 & 0.039 \\
\hline $\mathrm{H}_{3}$ & Persepsi Harga $\rightarrow$ Kepuasan Pelanggan & 0.426 & 0.000 & 0.410 \\
\hline
\end{tabular}




\begin{tabular}{|l|l|c|c|c|}
\hline $\mathrm{H}_{4}$ & Persepsi Harga $\rightarrow$ Loyalitas Pelanggan & 0.007 & 0.479 & 0.000 \\
\hline $\mathrm{H}_{5}$ & Kepercayaan $\rightarrow$ Kepuasan Pelanggan & 0.345 & 0.000 & 0.201 \\
\hline $\mathrm{H}_{6}$ & Kepercayaan $\rightarrow$ Loyalitas Pelanggan & 0.265 & 0.008 & 0.068 \\
\hline $\mathrm{H}_{7}$ & Kepuasan Pelanggan $\rightarrow$ Loyalitas Pelanggan & 0.362 & 0.003 & 0.089 \\
\hline $\mathrm{H}_{8}$ & $\begin{array}{l}\text { Kualitas Pelayanan } \rightarrow \text { Kepuasan Pelanggan } \rightarrow \\
\text { Loyalitas Pelanggan }\end{array}$ & 0.080 & 0.022 & - \\
\hline $\mathrm{H}_{9}$ & $\begin{array}{l}\text { Persepsi Harga } \rightarrow \text { Kepuasan Pelanggan } \rightarrow \\
\text { Loyalitas Pelanggan }\end{array}$ & 0.154 & 0.008 & - \\
\hline $\mathrm{H}_{10}$ & $\begin{array}{l}\text { Kepercayaan } \rightarrow \text { Kepuasan Pelanggan } \rightarrow \\
\text { Loyalitas Pelanggan }\end{array}$ & 0.125 & 0.021 & - \\
\hline
\end{tabular}

\section{DISKUSI}

Berdasarkan hasil seluruh pengujian secara statistik, kualitas pelayanan mampu mempengaruhi kepuasan pelanggan SPBU Pertamina di Jakarta, hal ini sejalan dengan penelitian sebelumnya (Cheng \&Rashid, 2013; Chakraborty, 2019; Ing et al., 2019). Berdasarkan penelitian sebelumnya, kualitas pelayanan yang berpengaruh terhadap kepuasan pelanggan tidak hanya berlaku pada industri perhotelan, konsumen muda perkotaan yang loyal dan restoran full-service, tetapi berlaku juga pada pelanggan SPBU Pertamina di Jakarta. Kualitas pelayanan juga mampu mempengaruhi loyalitas pelanggan SPBU Pertamina di Jakarta, hal ini sejalan dengan penelitian sebelumnya (Omoregie et al., 2019; Makanyeza \&Chikaze, 2017; Slack \&Singh, 2020). Berdasarkan penelitian sebelumnya kualitas pelayanan yang berpengaruh terhadap loyalitas pelanggan tidak hanya berlaku pada industri perbankan di Ghana dan bank di Zimbabwe, tetapi berlaku juga pada pelanggan SPBU Pertamina di Jakarta.Dalam penelitian Makanyeza \&Chikaze (2017) menyatakan bahwa semakin baik kualitas layanan, semakin banyak pelanggan yang loyal, kemudian kualitas pelayanan mampu mempengaruhi loyalitas pelanggan melalui kepuasan pelanggan SPBU Pertamina di Jakarta.Analisis mediasi tersebut merupakan partial mediation yang berarti kualitas pelayanan mampu mempengaruhi loyalitas pelanggan dengan atau tidak dengan melalui kepuasan pelanggan (Makanyeza \&Chikaze, 2017; Kim, 2011; Solimun \&Fernandes, 2018).

Persepsi harga mampu mempengaruhi kepuasan pelanggan SPBU Pertamina di Jakarta, hal ini sejalan dengan penelitian sebelumnya (Ing et al., 2019; Han \&Ryu, 2009; Prayitno, 2016). Berdasarkan penelitian sebelumnya, persepsi harga yang berpengaruhterhadap kepuasan pelanggan tidak hanya berlaku pada restoran full-service di Sabah, restoran three full-service di Amerika Serikat dan produk batik Indonesia di Surakarta, tetapi berlaku juga pada pelanggan SPBU Pertamina di Jakarta. Prayitno (2016) juga menyatakan bahwa pelanggan yang puas akan cenderung cocok dengan persepsi harga yang mereka peroleh.

Selanjutnya, persepsi harga tidak mampu mempengaruhi loyalitas pelanggan SPBU Pertamina di Jakarta, hal ini tidak sejalan dengan penelitian sebelumnya (Samah et al., 2015; Han \&Ryu, 2009; Cheng et al., 2008) yang menyatakan bahwa persepsi harga memiliki pengaruh positif terhadap loyalitas pelanggan. Dalam penelitian ini mayoritas pelanggan adalah orang yang berkecukupan untuk memenuhi kebutuhan bahan bakarnya di SPBU Pertamina, sehingga memungkinkan bahwa pelanggan tidak memiliki persepsi harga yang tersedia di SPBU Pertamina. Hal ini membuktikan bahwa persepsi harga yang mempengaruhi loyalitas pelanggan hanya berlaku pada beberapa penelitian saja, kemudian persepsi harga mampu memberi pengaruh loyalitas pelanggan melalui kepuasan pelanggan SPBU Pertamina di Jakarta. Analisis mediasi tersebut merupakan full mediation yang berarti persepsi harga mampu mempengaruhi loyalitas pelanggan melalui kepuasan pelanggan SPBU Pertamina, tetapi persepsi harga tidak mampu mempengaruhi loyalitas pelanggan SPBU Pertamina secara langsung. 
Kepercayaan mampu mempengaruhi kepuasan pelanggan SPBU Pertamina di Jakarta, hal ini sejalan dengan penelitian sebelumnya (Chakraborty, 2019; Kataria \&Saini, 2020; Omoregie et al., 2019). Berdasarkan penelitian sebelumnya, kepercayaan yang berpengaruh terhadap kepuasan pelanggan tidak hanya berlaku pada konsumen muda perkotaan yang loyal terhadap merek tertentu di Kolkata, perawatan mulut di India dan industri perbankan di Ghana, tetapi berlaku juga pada pelanggan SPBU Pertamina di Jakarta. Pelanggan dengan kepercayaan merek tinggi akan memiliki kepuasan dan kemauan tinggi untuk berkomitmen (Katarina \&Saini, 2020). Kepercayaan juga mempengaruhi loyalitas pelanggan SPBU Pertamina di Jakarta, hal ini sejalan dengan penelitian sebelumnya (Omoregie et al., 2019; Ramaseshanet al., 2013; Quoquab et al., 2019). Dalam penelitian sebelumnya, kepercayaan yang berpengaruh terhadap loyalitas pelanggan tidak hanya berlaku pada industri perbankan di Ghana dan makanan cepat saji muslim di Kuala Lumpur, tetapi berlaku juga pada pelanggan SPBU Pertamina di Jakarta. Ketika pelanggan mempercayai produk, mereka akan menunjukkan loyalitas terhadap merek atau produk (Quoquab et al., 2019), kemudian kepercayaan juga memiliki pengaruh terhadap loyalitas pelanggan melalui kepuasan pelanggan, analisis mediasi tersebut merupakan partial mediation yang berarti kepercayaan mampu mempengaruhi loyalitas pelanggan dengan ataupun tidak dengan melalui kepuasan pelanggan.

Kepuasan pelanggan mempengaruhi loyalitas pelanggan SPBU Pertamina di Jakarta, hal ini sejalan dengan penelitian sebelumnya (Omoegie et al., 2019; Han \&Ryu, 2009; Cheng \&Rashid, 2013). Berdasarkan penelitian sebelumnya, kepuasan pelanggan yang mempengaruhi loyalitas pelanggan tidak hanya berlaku pada industri perbankan di Ghana, industri perhotelan di Malaysia dan restoran three full-service di Amerika Serikat saja, tetapi berlaku juga pada pelanggan SPBU Pertamina di Jakarta. Omoregie et al. (2019) juga menyatakan bahwa ketika pelanggan memiliki persepsi bahwa kepuasan mereka dari layanan dimaksimalkan, mereka cenderung loyal. Artinya, ketika kepuasan dijamin, loyalitas terjamin.

\section{PENUTUP}

Berdasarkan hasil uji, analisis, dan diskusi maka dapat disimpulkan bahwa kualitas pelayanan dan kepercayaan mempengaruhi loyalitas pelanggan secara langsung dan secara tidak langsung melalui kepuasan pelanggan, tetapi persepsi harga hanya dapat mempengaruhi loyalitas pelanggan secara tidak langsung melalui kepuasan pelanggan.Keterbatasan yang dimiliki dalam penelitian ini adalah variabel yang digunakan untuk meneliti loyalitas pelanggan SPBU Pertamina di Jakarta hanya sebatas kualitas pelayanan, persepsi harga, kepercayaan dan kepuasan pelanggan dari sekian banyak variabel yang berpotensi memiliki pengaruh yang sama seperti citra merek, kualitas produk serta minat beli. Kemudian terdapat juga keterbatasan dalam jumlah sampel yaitu 100 respondenkarena keterbatasan waktu dalam pengumpulan sampel.

Penelitiandimasa yang mendatang disarankan untuk menggunakan variabel lain seperti seperti citra merek, kualitas produk, serta minat beli. Penambahan sampel dan perluasan batasan wilayah juga dapat dilakukan agar hasil data yang didapatkan menyerupai kondisi asli lapangan.Saran kepada SPBU Pertamina adalah mempertahankan dan meningkatkan kualitas pelayanannya untuk menjaga keloyalitasan pelanggan SPBU Pertamina, karena berdasarkan hasil pengisian kuesioner dalam penelitian ini, walaupun pelanggan yang lebih dominan merasa kualitas pelayanan SPBU Pertamina baik, tetapi masih ada sedikit pelanggan yang tidak dilayani dengan segera, merasa standar keamanan masih belum konsisten diterapkan dengan baik, serta kebersihan dan lahan yang cukup untuk pelanggan mengantri. Beberapa dari pelanggan tersebut perlu diyakinkan kembali dengan peningkatan kualitas pelayanan SPBU secara keseluruhan agar loyalitas antar pelanggan dan SPBU Pertamina tetap terjaga.SPBU Pertamina juga disarankan untuk menjaga kesesuaian harga BBM dengan daya beli pelanggan berdasarkan jenis BBM dan menjaga kepercayaan pelanggan dengan mempertahankan 
pengalaman baik yang telah dialami pelanggan serta mempertahankan kejujuran terhadap pelanggan dalam hal pengisian BBM SPBU Pertamina karena kepercayaan pelanggan dapat meningkatkan loyalitas pelanggan.

\section{DAFTAR RUJUKAN/PUSTAKA}

Chakraborty, D. (2019). Factors responsible for making young urban consumers brand loyal: A study on mobile network operators. Journal of Management Development, 38(7), 616-636. https://doi.org/10.1108/JMD-01-2019-0029

Cheng, B. L., \& Rashid, M. Z. A. (2013). Service quality and the mediating effect of corporate image on the relationship between customer satisfaction and customer loyalty in the Malaysian hotel industry. Gadjah Mada International Journal of Business, 15(2), 99112. https://doi.org/10.22146/gamaijb.5474

Cheng, T. C. E., Lai, L. C. F., \& Yeung, A. C. L. (2008). The driving forces of customer loyalty: A study of internet service providers in Hong Kong. International Journal of E-Business Research, 4(4), 26-42. https://doi.org/10.4018/jebr.2008100103

Chung, K. H., Yu, J. E., Choi, M. G., \& Shin, J. I. (2015). The effects of CSR on customer satisfaction and loyalty in China: The moderating role of corporate image. Journal of Economics, Business and Management, 3(5), 542547. https://doi.org/10.7763/JOEBM.2015.V3.243

Hair, J. F., Ringle, C. M., \& Sarstedt, M. (2011). PLS-SEM: Indeed a silver bullet. The Journal of Marketing Theory and Practice, 19(2), 139-151. https://doi.org/10.2753/MTP1069-6679190202

Hair, J. F., Risher, J. J., Sarstedt, M., \& Ringle, C. M. (2019). When to use and how to report the results of PLS-SEM. European Business Review, 31(1), 224. https://doi.org/10.1108/EBR-11-2018-0203

Han, H., \& Ryu, K. (2009). The roles of the physical environment, price perception, and customer satisfaction in determining customer loyalty in the restaurant industry. Journal of Hospitality \& Tourism Research,33(4), 487510. https://doi.org/10.1177/1096348009344212

Henseler, J., Ringle, C. M., \& Sarstedt, M. (2015). A new criterion for assessing discriminant validity in variance-based structural equation modeling. Journal of the Academy of Marketing Science, 43(1), 115-135. https://doi.org/10.1007/s11747-014-0403-8

Homburg, C., \& Giering, A. (2001). Personal characteristics as moderators of the relationship between customer satisfaction and loyalty: An empirical analysis. Psychology \& Marketing, 18(1), 43-66. https://doi.org/10.1002/1520-6793(200101)18:1<43::AIDMAR3>3.0.CO;2-I

Hur, W. M., Park, J., \& Kim, M. (2010). The role of commitment on the customer benefitsloyalty relationship in mobile service industry. The Service Industries Journal, 30(14), 2293-2309.https://doi.org/10.1080/02642060802629877

Iglesias, M. P., \& Guillen, M. J. Y. (2004). Perceived quality and price: Their impact on the satisfaction of restaurant customers. International Journal of Contemporary Hospitality Management, 16(6), 373-379.https://doi.org/10.1108/09596110410550824

Ing, P. G., Lin, N. Z., Xu, M., \& Thurasamy, R. (2019). Customer loyalty in Sabah full service restaurant. Asia Pacific Journal of Marketing and Logistics. Advance online publication. https://doi.org/10.1108/APJML-07-2019-0437

Izogo, E. E., \& Ogba, I. E. (2015). Service quality, customer satisfaction and loyalty in automobile repair services sector. International Journal of Quality \& Reliability Management, 32(3), 250-269. https://doi.org/10.1108/IJQRM-05-2013-0075

Katarina, S., \& Saini, V. (2020). The mediating impact of customer satisfaction in relation of brand equity and brand loyalty: An empirical synthesis and re-examination. South 
Asian Journal of Business Studies, 9(1), 62-87. https://doi.org/10.1108/SAJBS-03$\underline{2019-0046}$

Kim, H. J. (2011). Service orientation, service quality, customer satisfaction, and customer loyalty: Testing a structural model. Journal of Hospitality Marketing \& Management, 20(6), 619-637. https://doi.org/10.1080/19368623.2011.577698

Kitapci, O., Dortyol, I. T., Yaman, Z., \& Gulmez, M. (2013). The paths from service quality dimensions to customer loyalty: An application on supermarket customers. Management Research Review, 36(3), 239-255. https://doi.org/10.1108/01409171311306391

Kotler, P., \& Armstrong, G. (2010). Principles of Marketing (13th ed.). Pearson Prentince Hall.

Lin, H. H. (2015). The effects of price-matching guarantees on consumer response in an online retail context: The moderating role of consumer search costs. Journal of Service Theory and Practice, 25(6), 658-679. https://doi.org/10.1108/JSTP-05-2014-0100

Makanyeza, C., \& Chikazhe, L. (2017). Mediators of the relationship between service quality and customer loyalty: Evidence from the banking sector in Zimbabwe. International Journal of Bank Marketing, 35(3), 540-556. https://doi.org/10.1108/IJBM-11-2016$\underline{0164}$

Mathieu, J. E., \& Zajac, D. M. (1990). A review and meta-analysis of the antecedents, correlates, and consequences of organizational commitment. Psychological Bulletin, 108(2), 171-193. https://doi.org/10.1037/0033-2909.108.2.171

Moorman, C., Despande, R., \& Zaltman, G. (1993). Factor affecting trust in market research relationships. Journal of Marketing, 57(1), 81101.https://doi.org/10.1177/002224299305700106

Oliver, R. L. (1999). Whence consumer loyalty? Journal of Marketing, 63, 33-44. https://doi.org/10.1177/00222429990634s105

Oliver, R. L. (2015). Satisfaction:ABehavioral Perspective on The Customer (10 $\left.0^{\text {th }} \mathrm{ed}.\right)$. Routledge.

Omoregie, O. K., Addae, J. A., Coffie, S., Ampong, G. O. A., \& Ofori, K. S. (2019). Factors influencing consumer loyalty: Evidence from the Ghanaian retail banking industry. International Journal of Bank Marketing, 37(3), 798-820. https://doi.org/10.1108/IJBM-04-2018-0099

Parasuraman, A., Zeithaml, V. A., \& Berry, L. L. (1985). A conceptual model of service quality and its implications for future research. Journal of Marketing, 49(4), 41-50. https://doi.org/10.1177/002224298504900403

Patrick, A. S. (2002). Building trustworthy software agents. IEEE Internet Computing, 6(6), 46-53. https://doi.org/10.1109/MIC.2002.1067736

Prakash, A., \& Mohanty, R. P. (2012). Understanding service quality. Production Planning \& Control, 24(12), 1-16. https://doi.org/10.1080/09537287.2011.643929

Prayitno, T. H. (2016). The effect of price perception and convenience online shopping towards customer satisfaction of batik products in Indonesia. International Journal of Recent Advances in Multidisciplinary Research, 3(12), 2086-2091.

Quoquab, F., Sadom, N. Z. M., \& Mohammad, J. (2019). Driving customer loyalty in the Malaysian fast food industry: The role of halal logo, trust and perceived reputation. Journal of Islamic Marketing. Advance online publication. https://doi.org/10.1108/JIMA-01-2019-0010

Rahmawati, V. (2013). Intention to purchase the private label brand: The Roles of financial risk perception, price, and value consciousness for consumers of hypermarket in Surabaya. Journal of Economics, Business, and Accountancy Ventura, 16(1), 119-134. http://dx.doi.org/10.14414/jebav.v16i1.129 
Ramaseshan, B., Rabbanee, F. K., \& Hui, L. T. H. (2013). Effects of customer equity drivers on customer loyalty in B2B context. Journal of Business \& Industrial Marketing, 28(4), 335-346. https://doi.org/10.1108/08858621311313929

Rotter, J. B. (1967). A new scale for the measurement of interpersonal trust. Journal of Personality, 35(4), 651-665. https://doi.org/10.1111/j.1467-6494.1967.tb01454.x

Samah, I. H. A., Rashid, I. M. A., Rani, M. J. A., Rahman, N. I. A., Ali, M. A., \& Abdullah, M. F. S. (2015). The roles of price perception and physical environment in determining customer loyalty: Evidence from fast food restaurant of Malaysia. International Journal of Development Research, 5(5), 4366-4370.

Slack, N. J., \& Singh, G. (2020). The effect of service quality on customer satisfaction and loyalty and the mediating role of customer satisfaction: Supermarkets in Fiji. The TQM Journal, 32(3), 543-558. https://doi.org/10.1108/TQM-07-2019-0187

Solimun, \& Fernandes, A. A. R. (2018). The mediation effect of customer satisfaction in the relationship between service quality, service orientation, and marketing mix strategy to customer loyalty. Journal of Management Development, 37(1), 76-87. https://doi.org/10.1108/JMD-12-2016-0315

Thakur, R. (2016). Understanding customer engagement and loyalty: A case of mobile devices for shopping. Journal of Retailing and Consumer Services, 32, 151163. https://doi.org/10.1016/j.jretconser.2016.06.004

Widyastutir, S., \& Said, M. (2017). Consumer consideration in purchase decision of SPECS sports shoes product through brand image, product design and price perception. International Journal of Supply Chain Management, 6(4), 199-207.

Zhang, M., Xie, Y., Huang, L., \& He, Z. (2014). Service quality evaluation of car rental industry in China. International Journal of Quality \& Reliability Management, 31(1), 82-102. https://doi.org/10.1108/IJQRM-11-2012-0146

Zietsman, M. L., Mostert, P., \& Svensson, G. (2019). Perceived price and service quality as mediators between price fairness and perceived value in business banking relationships: A micro-enterprise perspective. International Journal of Bank Marketing, 37(1), 219. https://doi.org/10.1108/IJBM-07-2017-0144 